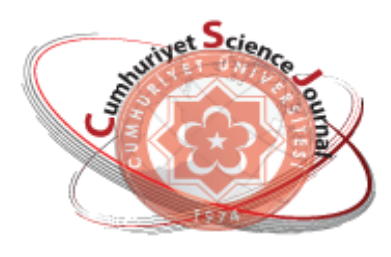

e-ISSN: 2587-246X

ISSN: $2587-2680$

\section{Cundenoiy ot Seionce Jownal}

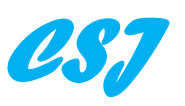

Cumhuriyet Sci. J., Vol.39-2(2018) 439-453

\title{
Quaternary Adsorption Effect of Nickel (II), Antimony (III), Manganese (II) and Copper (II) onto Living Two Green Microalgae
}

\author{
Tugba SENTURK ${ }^{*}$, Sukran YILDIZ ${ }^{1}$ \\ ${ }^{I}$ Manisa Celal Bayar University, Department of Biology, Faculty of Science and Art, Manisa, TURKEY \\ Received: 22.09.2017; Accepted: 08.05.2018 \\ http://dx.doi.org/10.17776/csj.434265
}

\begin{abstract}
This study aimed to investigate $\mathrm{Ni}, \mathrm{Sb}, \mathrm{Mn}$ and $\mathrm{Cu}$ adsorption from aqueous solution by Chlorella and Scenedesmus algae. The competitive adsorption efficiency of nickel $\left(\mathrm{Ni}^{2+}\right)$, antimony $\left(\mathrm{Sb}^{3+}\right)$, manganese $\left(\mathrm{Mn}^{2+}\right)$ and copper $\left(\mathrm{Cu}^{2+}\right)$ onto two living microalgae strains was studied from multi-metal aqueous solution for $24 \mathrm{~h}$ incubation time. After exposure, chlorophyll a-b, total carbohydrate and Atomic force microscopy (AFM) imaging were performed. Then adsorption isotherms models of metal ions were determined based on Langmuir and Freundlich isotherms. The adsorption capacity in multi-metal system was determined $6.47 \mathrm{mgg}^{-1}$ for antimony, $5.96 \mathrm{mgg}^{-1}$ for manganese, $28.57 \mathrm{mgg}^{-1}$ for copperand $10.71 \mathrm{mgg}^{-1}$ for nickel $(\mathrm{Cu}>\mathrm{Ni}>\mathrm{Sb}>\mathrm{Mn})$ by Chlorella respectively, whereas, and $10.82 \mathrm{mg} \mathrm{g}^{-1}$ for antimony, $7.07 \mathrm{mgg}^{-1}$ for manganese, $27.09 \mathrm{mgg}^{-1}$ for copper and $9.71 \mathrm{mgg}^{-1}$ for nickel $(\mathrm{Cu}>\mathrm{Sb}>\mathrm{Ni}>\mathrm{Mn})$ by Scenedesmus cells. According to AFM images, deformation was detected in two algae cell walls treated with heavy metals compared to untreated cells. For this study, Freundlich adsorption model best fitted the data for all metal ions with $1 / \mathrm{n}$ value $<1$. As a result, when the results obtained in the study are revealed that Chlorella and Scenedesmus cells were an effective adsorbent for removal of the four heavy metals, especially $\mathrm{Cu}^{2+}$ ions from aqueous solutions due to its high efficiency of $\mathrm{Cu}$ adsorption.
\end{abstract}

Keywords: Adsorption, AFM, Chlorella, heavy metal, Scenedesmus.

\section{Canlı İki Yeşil Mikroalg Üzerinde Nikel (II), Antimon (III), Mangan (II) ve Bakır (II)'in Dörtlü Adsorpsiyon Etkisi}

\begin{abstract}
Özet: $\mathrm{Bu}$ çalışmada, Chlorella ve Scenedesmus algleri kullanılarak sulu çözeltilerden $\mathrm{Ni}, \mathrm{Sb}, \mathrm{Mn}$ ve $\mathrm{Cu}$ adsorpsiyonunun araştırılması amaçlanmıştır. 24 saat inkübasyon süresi boyunca çoklu metal sulu çözeltiden canlı iki mikro alg suşu üzerinde nikel $\left(\mathrm{Ni}^{+2}\right)$, antimony $\left(\mathrm{Sb}^{+3}\right)$, mangan $\left(\mathrm{Mn}^{+2}\right)$ ve bakırın $\left(\mathrm{Cu}^{+2}\right)$ yarışmalı adsorpsiyon verimliliği incelenmiştir. Metal uygulaması sonrasında, klorofil a-b, toplam karbonhidrat ve atomik kuvvet mikroskobu (AFM) görüntülemesi analiz edilmiştir. Metal iyonlarının adsorpsiyon izoterm modelleri Langmuir ve Freundlich izotermlerine göre belirlenmiştir. Çoklu metal sisteminin Scenedesmus hücreleri tarafından sırasıyla antimon: $10.82 \mathrm{mgg}^{-1}$, mangan: $7.07 \mathrm{mgg}^{-1}$, bakır: $27.09 \mathrm{mgg}^{-1}$ ve nikel: $9.71 \mathrm{mgg}^{-1}$ $(\mathrm{Cu}>\mathrm{Sb}>\mathrm{Ni}>\mathrm{Mn})$ olarak belirlenirken Chlorella için adsorbsiyon kapasitesi antimon: $6.47 \mathrm{mgg}^{-1}$, mangan: 5.96 mg g ${ }^{-1}$, bakır: $28.57 \mathrm{mgg}^{-1}$ ve nikel: $10.71 \mathrm{mgg}^{-1}(\mathrm{Cu}>\mathrm{Ni}>\mathrm{Sb}>\mathrm{Mn})$ olarak belirlenmiştir. AFM görüntülerine göre, ağır metallere maruz bırakılmış iki algin hücre duvarında, maruz bırakılmamış hücrelere kıyasla deformasyon tespit edilmiştir. Bu çalışma için Freundlich adsorbsiyon modeli 1/n değerinin 1'den küçük olmasıyla tüm metal iyonları için uygundur. Sonuç olarak, çalışmada elde edilen sonuçlar değerlendirildiğinde, Chlorella ve Scenedesmus hücrelerinin, dört ağır metali, özellikle $\mathrm{Cu}$ adsorpsiyonunun yüksek verimliliği nedeniyle, $\mathrm{Cu}^{+2}$ iyonlarının sulu çözeltilerden uzaklaştırılmasında etkili bir adsorbent olduğunu ortaya koymuştur.
\end{abstract}

Anahtar Kelimeler: Adsorpsiyon, AFM, Chlorella, ağır metal, Scenedesmus. 


\section{INTRODUCTION}

As a result of the integration of the heavy metal contamination into the food chain has also become a serious problem for human health. The biosorption and bioaccumulation of metals by algae, bacteria, fungi and yeast, dead or alive, has been extensively studied in the last two decades because of their potential use in the treatment of sewage loaded with heavy metals. Of the microorganism studied, algae is gaining increasing attention, due to the fact that algae is a rich source in the aquatic environment, relatively cheap to process and able to accumulate high metal content [1-4].

Planktonic algae used to test the effects of different chemicals released into the aquatic environment are very sensitive indicators. Microalgae are very sensitive to changes in their environment. In response to trace levels in the concentration to various organic and inorganic pollutants including heavy metals, changes take place in their overall metabolism. Microalgae are therefore often used as biological sensors for detecting potential toxic effects of heavy metals like copper, nickel, zinc, cadmium etc. [5-7]. These metals are essential constituents but in higher concentrations, it adversely affects the aquatic ecosystem and indirectly affects the human health [8].

In this study, copper, manganese, nickel and antimony, mainly present in the effluent from industry as well as in fresh water, have been tested that gets adsorbed by the two green algae (Chlorella and Scenedesmus). Two mathematical models have been used in this study: Freundlich and Langmuir. Atomic force microscopy (AFM) was used to study the interaction between heavy metal ions and Chlorella and Scenedesmus cell walls.

\section{MATERIALS AND METHODS}

\subsection{Microalgae strain and culture medium}

Chlorella and Scenedesmus cells were obtained from Culture Collection of Algal Biotechnology Department (Ege University, Izmir, Turkey). Stock cultures were cultivated in BG-11 medium [9] with 16:8 $\mathrm{h}$ of light-dark cycle under illumination of white fluorescent lamps (20 E $\mathrm{m}^{-2} \mathrm{~s}^{-1} \pm 20 \%$ ). An orbital shaker with $100 \mathrm{rpm}$ was used to maintain culture in turbulent conditions at $28 \pm 1{ }^{\circ} \mathrm{C}$.

\subsection{Biomass concentrations and pretreatment}

The growth of algae and biomass concentration was monitored by measuring optical density at a wavelength of $660 \mathrm{~nm}$ and $730 \mathrm{~nm}$ for 30 days. Cells were harvested from the culture by centrifugation. The biomass pellets collected were then washed with distilled water and centrifuged again for the removal of medium.

\subsection{Dissolutions}

Experiments were performed using synthetic single-metal solutions of $\mathrm{Sb}, \mathrm{Mn}, \mathrm{Cu}$ and $\mathrm{Ni}$ prepared from chemical reactants of analytical grade: $\quad \mathrm{C}_{8} \mathrm{H}_{4} \mathrm{~K}_{2} \mathrm{O}_{12} \mathrm{Sb}_{2} \cdot \mathrm{H}_{2} \mathrm{O}, \quad \mathrm{MnSO}_{4} \cdot \mathrm{H}_{2} \mathrm{O}$, $\mathrm{CuSO}_{4} .5 \mathrm{H}_{2} \mathrm{O}$ and $\mathrm{NiSO}_{4} \cdot 6 \mathrm{H}_{2} \mathrm{O}$, respectively. Stock solutions of the heavy metals were prepared, from which concentrations 2.5-100 ppm were used in case of algal tolerance experiments. The microalgae Chlorella and Scenedesmus were used in the experiment of heavy metal removal using the algal concentrations $10 \mathrm{~mL}$. The metal concentration used was $40 \mathrm{~mL}$ and the exposure time was $24 \mathrm{~h}$. $\mathrm{pH}$ was adjusted to 4-5 for all heavy metalsremoval assay and incubation was performed at the previously mentioned conditions. After preparing solutions with an initial concentration of 2.5, 5, 10, 25, 50 and 100 
ppm of $\mathrm{Sb}, \mathrm{Mn}, \mathrm{Ni}$ and $\mathrm{Cu}$ at $\mathrm{pH}$ 5- 5.5, respectively.

\subsection{Analytical procedure}

Dry weight biomass $\left(\mathrm{mg} \mathrm{L}^{-1}\right)$ was measured gravimetrically using $10 \mathrm{~mL}$ of the sample. A definite volume $(10 \mathrm{~mL})$ of algal suspension was filtered through Whatman GF/C filter membrane (47 $\mathrm{mm}$ in diameter, $0.22 \mu \mathrm{m}$ in pore size) and dried overnight in an oven at $80^{\circ} \mathrm{C}$. Data were given as $\mathrm{mg} \mathrm{mL}^{-1}$ algal suspension.

2.5. Chlorophyll a-b ( $\mu \mathrm{g} \mathrm{L}^{-1}$ ) was measured after extraction in $90 \%$ aqueous acetone [10]. For determination of pigment concentrations, 10 $\mathrm{mL}$ of culture was filtered using GF/C filters. An aliquot of the sample was centrifuged at 12000 rpm for $5 \mathrm{~min}$ and supernatant discarded. The pellet was suspended in $10 \mathrm{~mL}$ of boiling acetone at $4^{\circ} \mathrm{C}$ and stored in dark for $24 \mathrm{~h}$. Chlorophyll $a-b$ were thus extracted in acetone and the absorbance of acetone solution was measured at $630 \mathrm{~nm}, 645 \mathrm{~nm}, 665 \mathrm{~nm}$, and $750 \mathrm{~nm}$ using a spectrophotometer with $90 \%$ acetone as blank.

2.6. Total carbohydrate contents $\left(\mathrm{mg} \mathrm{mL}^{-1}\right)$ were measured using the phenol-sulfuric acid assay and using glucose as a standard. $1 \mathrm{~mL}$ aliquots of the cultures were used to quantify spectrophotometrically the total carbohydrate content by the phenol-sulfuric acid assay [11].

\subsection{AFM (Atomic Force Microscope)}

At the end of the bioremoval experiments, algal pellets were harvested by centrifugation (1000 $\mathrm{rpm}$ ) and prepared for AFM (hpAFM-IN) for the detection of heavy metal ions damage on the cell surface. This was performed at the Experimental Science Applications and Research Center Lab., Celal Bayar Univ., Manisa/Turkey.

\subsection{Chemical analysis}

The effect of co-cations on the adsorption of $\mathrm{Sb}$, $\mathrm{Mn}, \mathrm{Ni}$ and $\mathrm{Cu}$ by Chlorella and Scenedesmus was studied in quaternary component systems. Experimental design used in the study consisted of system, viz. $\mathrm{Sb}+\mathrm{Mn}+\mathrm{Ni}+\mathrm{Cu}$ at $2.5 \mathrm{ppm}$, $\mathrm{Sb}+\mathrm{Mn}+\mathrm{Ni}+\mathrm{Cu}$ at $5 \mathrm{ppm}, \mathrm{Sb}+\mathrm{Mn}+\mathrm{Ni}+\mathrm{Cu}$ at 10 ppm, $\mathrm{Sb}+\mathrm{Mn}+\mathrm{Ni}+\mathrm{Cu}$ at $25 \mathrm{ppm}, \mathrm{Sb}+\mathrm{Mn}+\mathrm{Ni}+\mathrm{Cu}$ at $50 \mathrm{ppm}$ and $\mathrm{Sb}+\mathrm{Mn}+\mathrm{Ni}+\mathrm{Cu}$ at $100 \mathrm{ppm}$. Biosorption tests were carried out in $100 \mathrm{~mL}$ Erlenmeyer flasks placed on a magnetic stirring plate. Each flask contained the solution $(40 \mathrm{~mL})$ and sufficient biomass (10mL). Periodically, 10 $\mathrm{mL}$ of sample was removed for analysis, and the $\mathrm{pH}$ was measured. After centrifugation at 4000 rpm to separate the biomass, the samples were analyzed by ICP-MS (Inductively Coupled Plasma-Mass Spectrometer-Agilent 7700) [12].The metal uptake loading capacity qe (mg of metal per g of adsorbent) and efficiency (\%) for each sorption system was determined using Eq. 1 and Eq. 2:

$\mathrm{q}\left(\mathrm{mg} \mathrm{g}^{-1}\right)=\mathrm{q}\left(\mathrm{mg} \mathrm{g}^{-1}\right)=\frac{\mathrm{C}_{\mathrm{i}}-\mathrm{Ce}}{\mathrm{m}} \mathrm{xV}$

$(\%)=100 x \frac{C_{i}-C_{e}}{C_{i}}$

Where $\mathrm{q}$ is the metal uptake ( $\mathrm{mg} \mathrm{g}^{-1}$ of biomass); $C_{i}$ and $C_{e}$ are the metal concentrations before and after adsorption $\left(\mathrm{mg} \mathrm{mL}^{-1}\right)$, respectively; $m$ is the mass of biosorbent used (g) and $V$ is the volume of solution $(\mathrm{mL})$.

\subsection{Adsorption isotherm models}

The adsorption equilibrium isotherms were evaluated in terms of maximum sorption capacity and sorption affinity. Among the several isotherm equations, two isotherms (Langmuir and Freundlich adsorption isotherms) were investigated, which are widely used to analyses data for water and wastewater treatment applications [13]. Freundlich isotherm model is derived for describing single-component adsorption equilibria on heterogeneous surfaces. Langmuir isotherm represents a single layer and uniform adsorbent without interactions between adsorbed molecules. In the current study, the Freundlich (Eq. 3) and Langmuir (Eq. 4) models were used to determining the concentration of the adsorbed material. If $1 / n=0$, the adsorption process is irreversible. If $1<1 / \mathrm{n}<0$, it is desired. If $1 / n>0$, it is undesirable $[14,15]$. 
$\log q_{e}=\log K_{F}+\left(\frac{1}{n}\right) \log C_{e} \quad$ (Eq. 3).

$\mathrm{q}_{\mathrm{e}}$ : the amount of metal adsorbed $\left(\mathrm{mg} \mathrm{g}^{-1}\right)$.

$\mathrm{K}_{\mathrm{F}}$ : Adsorption capacity at unit concentration (L $\left.\mathrm{g}^{-1}\right)$.

1/n: Intensity of adsorption $\left(\mathrm{L} \mathrm{g}^{-1}\right)$.

$\mathrm{C}_{\mathrm{e}}$ : the equilibrium concentration of metal ion (mg L-1).

In the Langmuir model, $\mathrm{q}_{\mathrm{m}}$ and $\mathrm{b}$ are Langmuir parameters, which are the maximum adsorption capacity and associated energy, respectively. The equilibrium parameter $\left(\mathrm{R}_{\mathrm{L}}\right)$ is the basis of the Langmuir isotherm, which is defined by equation, $\mathrm{R}_{\mathrm{L}}=1 /\left(1+\mathrm{bC}_{0}\right)$ [14]. In this equation, $\mathrm{C}_{0}$ is the initial concentration and $\mathrm{R}_{\mathrm{L}}$ is the type of isotherms. $1<\mathrm{R}_{\mathrm{L}}<0$ is favourable adsorption, $\mathrm{R}_{\mathrm{L}}>1$ is for undesirable adsorption, $\mathrm{R}_{\mathrm{L}}=1$ shows linear adsorption and $\mathrm{R}_{\mathrm{L}}=0$ demonstrates irreversible adsorption [16]. The $\mathrm{R}_{\mathrm{L}}$ value was calculated at $50 \mathrm{ppm}$ of initial metal concentration.

$\frac{\mathrm{C}_{\mathrm{e}}}{\mathrm{q}_{\mathrm{e}}}=\frac{1}{\mathrm{q}_{\mathrm{m}} \mathrm{b}}+\frac{\mathrm{C}_{\mathrm{e}}}{\mathrm{q}_{\mathrm{m}}}($ Eq. 4).

$\mathrm{q}_{\mathrm{m}}$ : Langmuir maximum adsorption capacity $\left(\mathrm{mg} \mathrm{g}^{-1}\right)$.

b: the constant related to free energy of adsorption $\left(\mathrm{L} \mathrm{mg}^{-1}\right)$.

\section{RESULTS}

\subsection{Analysis results of the chlorophyll a-b ( $\mu \mathrm{g}$ $\left.\boldsymbol{L}^{-1}\right)$}

Control chlorophyll-a values of Chlorella and Scenedesmus cells were determined 0.5149 and $0.3602 \mu \mathrm{g} \mathrm{\textrm {L } ^ { - 1 }}$, respectively. After metals treatment, the average values of chlorophyll-a

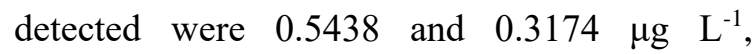
respectively. Compare to the control without 10 ppm combined heavy metal exposure, chlorophyll-a biosynthesis showed a stimulatory effect in both organisms.
For Chlorella cells, control chlorophyll-b value was determined to be $1.6146 \mu \mathrm{g} \mathrm{\textrm {L } ^ { - 1 }}$ which decreased to $0.8117 \mu \mathrm{g} \mathrm{L}^{-1}$ at the end of the $24 \mathrm{~h}$ test period. Similar to these results, for Scenedesmus cells, the initial chlorophyll-b value, which was found to be $0.5246 \mu \mathrm{g} \mathrm{L}^{-1}$, decreased to $0.2791 \mu \mathrm{g} \mathrm{L}^{-1}$ at the end of the experiment. Except for metals applied at a concentration of $10 \mathrm{ppm}$ in Chlorella, the coadministration of all heavy metals in both of the relevant organism cells negatively affected the chlorophyll-b biosynthesis.

These results show that the formation of photosynthetic pigments, in particular chlorophyll-b, synchronized with the growth of the microalgal cells, making it an indicator for evaluating the removal efficiency of the heavy metal ions. The two algae intolerated the toxicity of all combined heavy metals even at higher concentrations (80-100 ppm), moreover the lower concentration (5-10 ppm) (Table 1). The combined application of the four low and high concentrations of heavy metals tested resulted in a decrease in the chlorophyll-a content while the chlorophyll-b content increased of both green algae at $10 \mathrm{ppm}$ metal solutions.

\subsection{Analysis results of the carbohydrate (mg $\left.m L^{-1}\right)$}

As a result of the application of co-metals together with the organisms, the carbohydrate value of Chlorella cells was recorded as 0.9562 $\mathrm{mg} \mathrm{mL} \mathrm{m}^{-1}$. At the end of the study, this value was determined as average $0.8531 \mathrm{mg} \mathrm{mL}^{-1}$. These values have been found to fall especially in mixtures with high concentration of metals (>10 ppm) (Figure 1). Contrary to these results, Scenedesmus cells showed an increase from $0.0209 \mathrm{mg} \mathrm{mL}^{-1}$ to $0.0646 \mathrm{mg} \mathrm{mL}^{-1}$, especially at $2.5 \mathrm{ppm}$ heavy metal concentration. While lower concentration of four metal ions $\left(2.5-5 \mathrm{mg} \mathrm{L}^{-1}\right)$ enhanced the algal growth (total carbohydrate), elevated concentrations $\left(10-100 \mathrm{mg} \mathrm{L}^{-1}\right)$ were inhibitory to the growth especially in Chlorella cells. This situation, which is observed in relation to carbohydrate synthesis, can be said to 
be effective of carbohydrate synthesis on the growth and survival of two algal species used in the study. This suggests that the photosynthetic apparatus yield is closely related to the yield of carbohydrate and nitrogen metabolism. The arrangement between carbohydrate and $\mathrm{N}$ metabolism is associated with heavy metal tolerance. It may result in the metabolic inhibitor effect of heavy metals on both components (carbohydrate and chlorophyll) [17].

Table 1. Effect of co-application of metals to chlorophyll-a and b and total carbohydrate of Chlorella and Scenedesmus.

\begin{tabular}{|c|c|c|c|c|c|c|}
\hline \multirow[b]{2}{*}{$\begin{array}{c}\text { Metal } \\
\text { concentrations } \\
(\mathbf{p p m})\end{array}$} & \multicolumn{2}{|c|}{ Chlorella } & \multicolumn{2}{|c|}{ Scenedesmus sp. } & \multirow{2}{*}{$\begin{array}{c}\text { Chlorella } \\
\text { Total } \\
\text { Carbohydrate } \\
\left(\mathrm{mg} \mathrm{mL}^{-1}\right)\end{array}$} & \multirow{2}{*}{$\begin{array}{c}\text { Scenedesmus } \\
\text { Total } \\
\text { Carbohydrate } \\
\left(\mathrm{mg} \mathrm{mL}^{-1}\right)\end{array}$} \\
\hline & $\begin{array}{c}\text { Chlorophyll- } \\
\text { a }\left(\mu \mathrm{g} \mathrm{L}^{-1}\right)\end{array}$ & $\begin{array}{c}\text { Chlorophyll- } \\
\text { b }\left(\mu \mathrm{g} \mathrm{L}^{-1}\right)\end{array}$ & $\begin{array}{c}\text { Chlorophyll- } \\
\text { a }\left(\mu \mathrm{g} \mathrm{L}^{-1}\right)\end{array}$ & $\begin{array}{c}\text { Chlorophyll- } \\
\text { b }\left(\mu \mathrm{g} \mathrm{L}^{-1}\right)\end{array}$ & & \\
\hline Control & 0.5149 & 1.6146 & 0.3602 & 0.5246 & 0.9562 & 0.0209 \\
\hline 2.5 & 0.5239 & 0.8802 & 0.3812 & 0.4894 & 0.9871 & 0.2529 \\
\hline 5 & 0.6695 & 0.6656 & 0.2472 & 0.2610 & 0.9900 & 0.0159 \\
\hline 10 & 0.2227 & 0.9836 & 0.2491 & 0.2059 & 0.9042 & 0.0438 \\
\hline 25 & 0.6229 & 0.3238 & 0.2910 & 0.1879 & 0.8073 & 0.0380 \\
\hline 50 & 0.6546 & 0.4958 & 0.3630 & 0.2552 & 0.6468 & 0.0316 \\
\hline 100 & 0.5695 & 0.5211 & 0.3731 & 0.2753 & 0.7835 & 0.0056 \\
\hline Avarage values & 0.5438 & 0.8117 & 0.3174 & 0.2791 & 0.8531 & 0.0646 \\
\hline
\end{tabular}

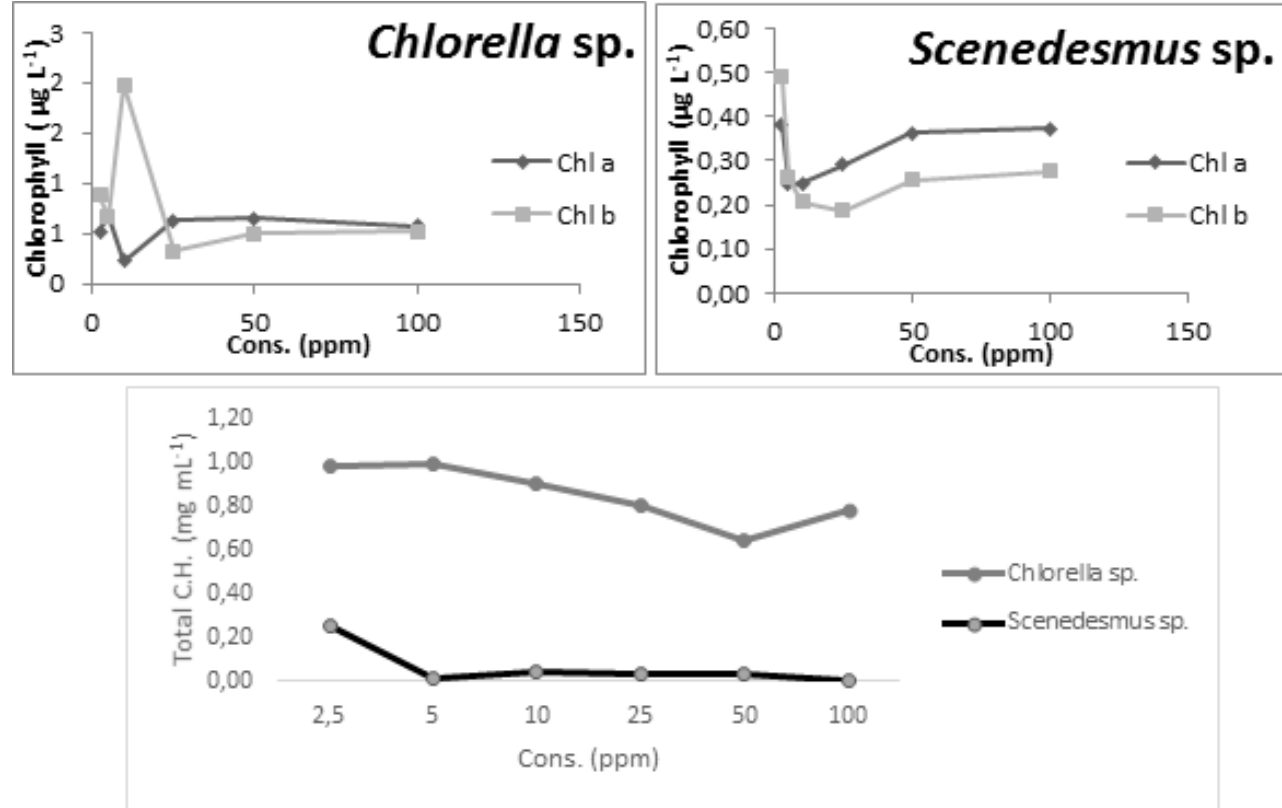

Figure 1. Effect of co-application of metals to chlorophyll-a and b and total carbohydrate of Chlorella and Scenedesmus.

\subsection{Analysis results of the heavy metal uptake ( $\left.m g^{-1}\right)$ and efficiency (\%)}

Samples were quantified by Coupled Plasma Mass Spectroscopy (ICP-MS). According to the results for Chlorella, the lowest and highest percentages of metal removal are identify as 9,10 (50 ppm) - 53,08 (2,5 ppm) for Antimony; 2,09 (50 ppm) - 84,23 (50 ppm) for Nickel; 6,24 (10 ppm) - 56,25 (2,5 ppm) for Manganese and
12,83 (25 ppm) - 77,27 (2,5 ppm) for Copper, respectively (Table 2). Besides, the average removal values for antimony, manganese, nickel and copper heavy metals on Chlorella cells were determined as $6.47 ; 5.96 ; 10,71$ and $28,57 \mathrm{mg} \mathrm{g}^{-}$ ${ }^{1}$, respectively $(\mathrm{Cu}>\mathrm{Ni}>\mathrm{Sb}>\mathrm{Mn})$.

For Scenedesmus cells, the lowest and highest percentages of metal removal are determined as 1,34 (50 ppm) - 59,98 (5 ppm) for Antimony; 
12,99 (5 ppm) - 42,57 (10 ppm) for Nickel; 2,88 (5 ppm) - 31,43 (2,5 ppm) for Manganese and 4,74 (5 ppm) - 33,02 (2,5 ppm) for Copper, respectively. The average removal values for antimony, manganese, nickel and copper heavy metals on Scenedesmus cells were determined as
10,$82 ; 7,07 ; 9,71$ ve $27,09 \mathrm{mg} \mathrm{g}^{-1}$, respectively $(\mathrm{Cu}>\mathrm{Sb}>\mathrm{Ni}>\mathrm{Mn})$. The obtained results showed that $\mathrm{Mn}^{2+}$ was the most toxic of the four metal ions to the test algae even at low concentration (<10 $\mathrm{mg} \mathrm{L}^{-1}$ ) (Figure 2).

Table 2. Metal ion binding capacities and percent of metal ion removal of Chlorella and Scenedesmus. (Data represent mean values).

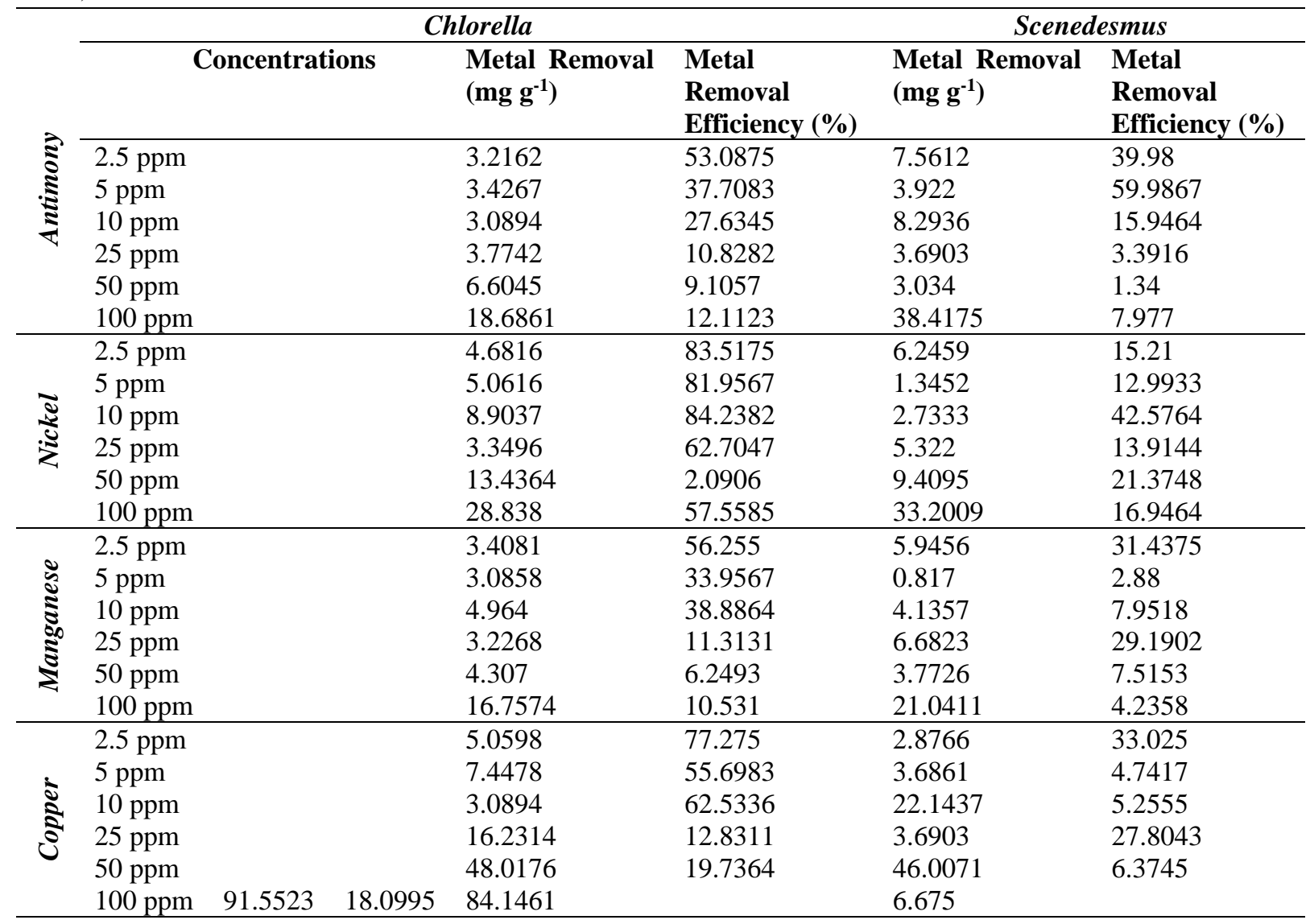
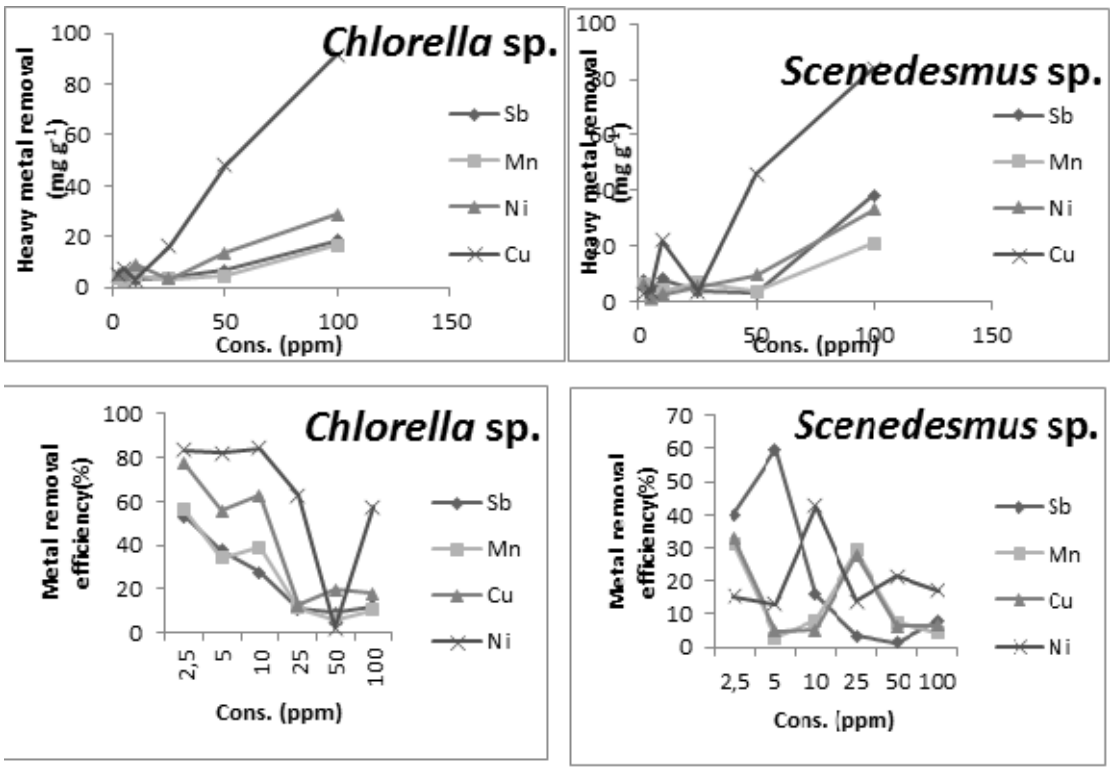

Figure 2.Metal ion binding capacities and percent of metal ion removal of Chlorella and Scenedesmus 


\subsection{Statistical results}

The results of Langmuir and Freundlich isotherms are presented in Table 3.

Table 3. Langmuir and Freundlich isotherm models for antimony, manganese, nickel and copper ions adsorption by Chlorella and Spirulina cells.

\begin{tabular}{|c|c|c|c|c|c|}
\hline \multirow{9}{*}{ 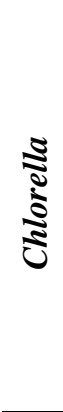 } & Adsorption Isotherm Constants & $\mathbf{S b}$ & Mn & $\mathbf{N i}$ & $\mathbf{C u}$ \\
\hline & Freundlich & & & & \\
\hline & $1 / \mathrm{n}_{\left(\mathrm{L} \mathrm{g}^{-1}\right)}$ & 0.825 & 0.813 & 0.777 & 0.86 \\
\hline & $\mathrm{K}_{\mathrm{F}}\left(\mathrm{L} \mathrm{g}^{-1}\right)$ & 1.251 & 0.81 & 1.285 & 1.162 \\
\hline & $\mathrm{R}^{2}$ & 0.9963 & 0.9416 & 0.9007 & 0.9499 \\
\hline & Langmuir & & & & \\
\hline & $\mathrm{q}_{\mathrm{m}}\left(\mathrm{mg} \mathrm{g}^{-1}\right)$ & 29.644 & 26.832 & 31.414 & 72.832 \\
\hline & $\mathrm{R}_{\mathrm{L}}\left(\mathrm{L} \mathrm{mg}^{-1}\right)$ & 1.666 & 0.555 & 2.503 & 1.860 \\
\hline & $\mathrm{R}^{2}$ & 0.0113 & 0.7101 & 0.021 & 0.1586 \\
\hline \multirow{8}{*}{ 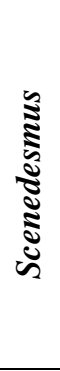 } & Freundlich & & & & \\
\hline & $1 / \mathrm{n}_{\left(\mathrm{L} \mathrm{g}^{-1}\right)}$ & 0.375 & 0.179 & 0.251 & 0.102 \\
\hline & $\mathrm{K}_{\mathrm{f}}\left(\mathrm{L} \mathrm{g}^{-1}\right)$ & 0.941 & 0.350 & 0.875 & 0.177 \\
\hline & $\mathrm{R}^{2}$ & 0.0009 & 0.5689 & 0.8972 & 0.9709 \\
\hline & Langmuir & & & & \\
\hline & $\mathrm{q}_{\mathrm{m}}\left(\mathrm{mg} \mathrm{g}^{-1}\right)$ & 30.1207 & 26.812 & 28.8546 & 66.153 \\
\hline & $\mathrm{R}_{\mathrm{L}}\left(\mathrm{L} \mathrm{mg}^{-1}\right)$ & 0.083 & 0.355 & 0.117 & 0.015 \\
\hline & $\mathrm{R}^{2}$ & 0.4293 & 0.2096 & 0.1529 & 0.6937 \\
\hline
\end{tabular}

We concluded that maximum adsorption capacity of copper calculated from Langmuir isotherm was around 72.832 and $66.153 \mathrm{mg} \mathrm{g}^{-1}$ for Chlorella and Scenedesmus, respectively. Compared to Scenedesmus $\left(\mathrm{q}_{\mathrm{m}}=26.812\right.$, $30.1207,28.8546$ and $66.153 \mathrm{mg} \mathrm{g}^{-1}$ for $\mathrm{Mn}^{2+}$, $\mathrm{Sb}^{3+}, \mathrm{Ni}^{2+}$ and $\mathrm{Cu}^{2+}$, respectively), Chlorella behaved as a better biosorbent because of higher equilibrium sorption capacity $\left(\mathrm{q}_{\mathrm{m}}=26.812\right.$, $29.644,31.414$ and $72.832 \mathrm{mg} \mathrm{g}^{-1}$, respectively).
The experimental data showed that for Chlorella and Scenedesmus cells, Langmuir isotherm model was applied to experimental equilibrium data of metal ions adsorption $\left(\mathrm{R}_{\mathrm{L}}\right)$ for $\mathrm{Mn}, \mathrm{Sb}, \mathrm{Ni}$ and $\mathrm{Cu}$ were found between $0.555-2.503$ and 0.015-0.355, respectively (Figure 3-6). For Chlorella and Scenedesmus cells, $1 / \mathrm{n}$ value was determined between 0.777-0.860 and 0.1020.375 , respectively. 


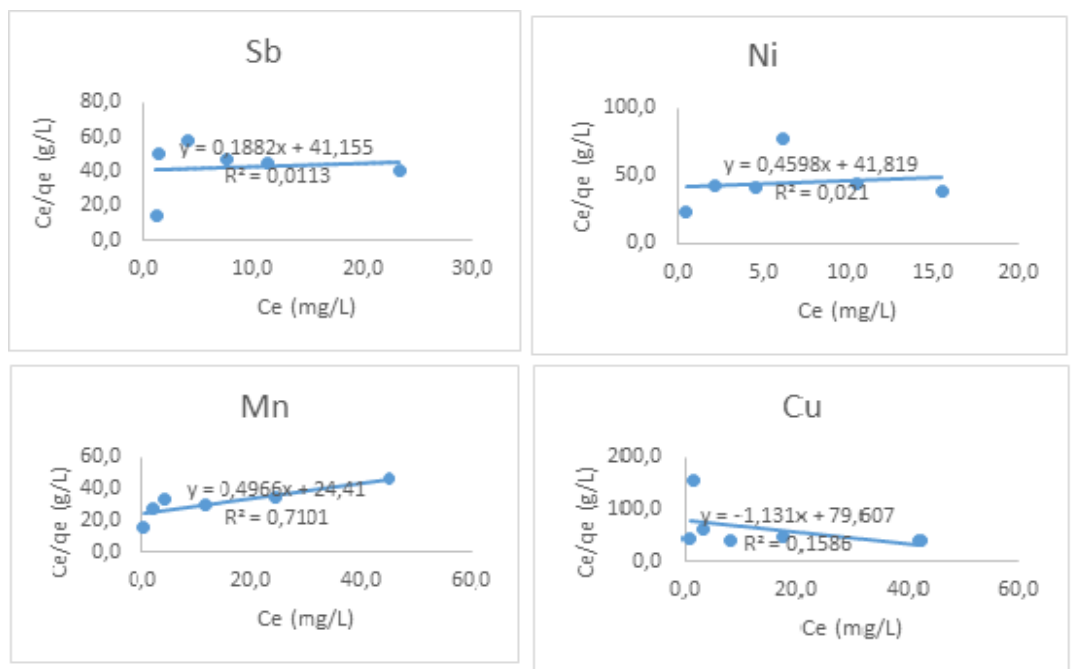

Figure 3. Langmuir adsorption isotherm of Chlorella on $\mathrm{Sb}, \mathrm{Mn}, \mathrm{Ni}$ and $\mathrm{Cu}$.
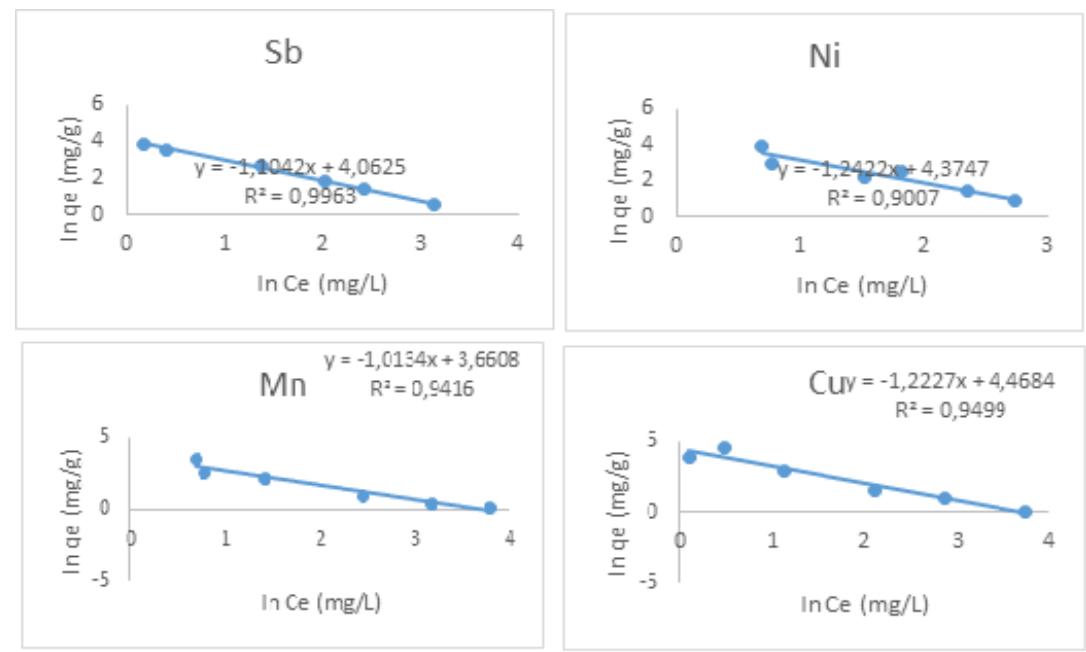

Figure 4. Freundlich adsorption isotherm of Chlorella on $\mathrm{Sb}, \mathrm{Mn}, \mathrm{Ni}$ and $\mathrm{Cu}$.

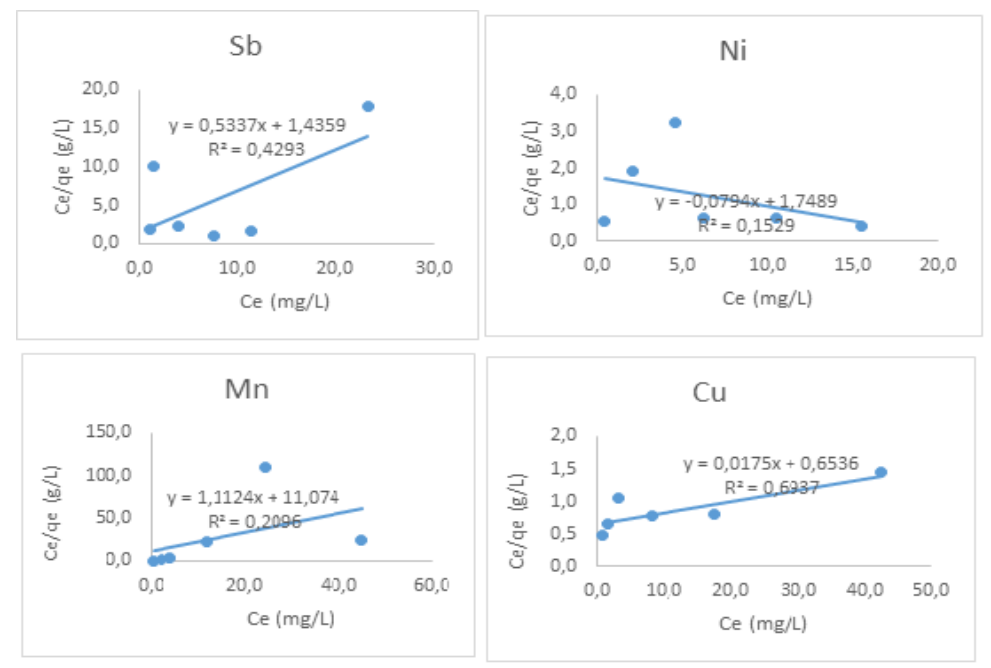

Figure 5. Langmuir adsorption isotherm of Scenedesmus on $\mathrm{Sb}, \mathrm{Mn}, \mathrm{Ni}$ and $\mathrm{Cu}$. 


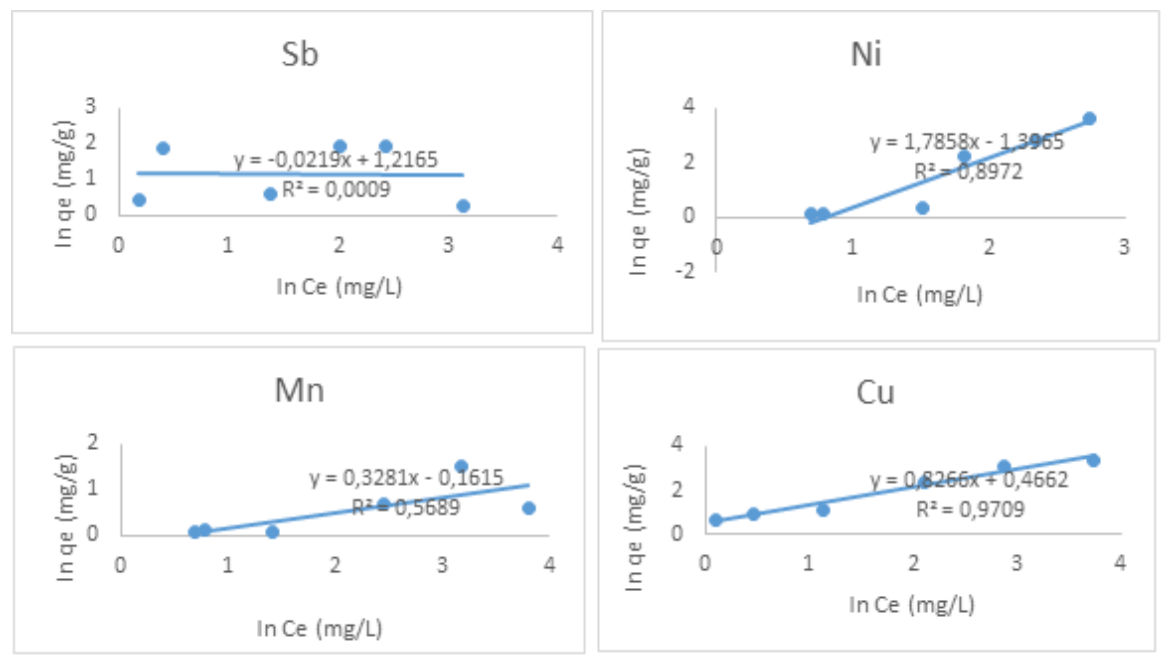

Figure 6. Freundlich adsorption isotherm of Scenedesmus on $\mathrm{Sb}, \mathrm{Mn}, \mathrm{Ni}$ and $\mathrm{Cu}$.

\subsection{AFM Images}

Atomic force microscopy (AFM), Scanning electron microscopy (SEM) and Fourier transform infrared spectroscopy (FTIR) analyses are the most useful methods for the surface characterization and elemental analysis of materials [18,19]. AFM analyses were therefore applied to study the surface morphologies of the biosorbents after the biosorptions of each metal. The AFM images of Chlorella cells were determined after the treatment with the metal mixture at the concentration of $10 \mathrm{ppm}$, which is the heaviest metal adsorption. According to the findings, differences were determined between untreated surface topology of both organisms and the cell surfaces in which heavy metals are caused (Figure 7-8). Deformation was detected in cells treated-heavy metals as compared with untreated cells. The AFM images of Chlorella cells exposed to $\mathrm{Cu}, \mathrm{Ni}, \mathrm{Sb}$ and $\mathrm{Mn}$ ions presented in Figure 8 show that the surfaces of such cells were relatively dynamic and rough compared to the unexposed cells, the surfaces of which were more uniform and smooth. This may have been the result of heavy metal binding to the cell wall surface. 


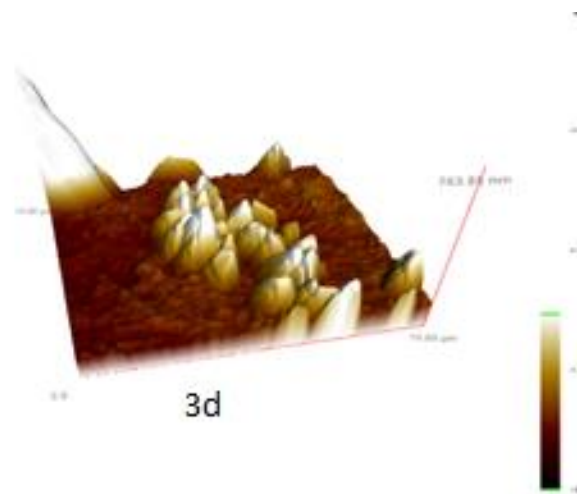

\begin{tabular}{|l|}
\multicolumn{1}{c|}{ Roughness Parameters } \\
\hline \multicolumn{1}{c|}{ Coefficient } \\
\hline Average (Ra) \\
\hline Root Mean Squre (Rq) \\
\hline Skewness (Rsk) \\
\hline Murtosis (Rku) \\
\hline Maximum (Rp) \\
\hline Meak To Pesk (Rt) \\
\hline Ten Point Height (Rz) \\
\hline
\end{tabular}
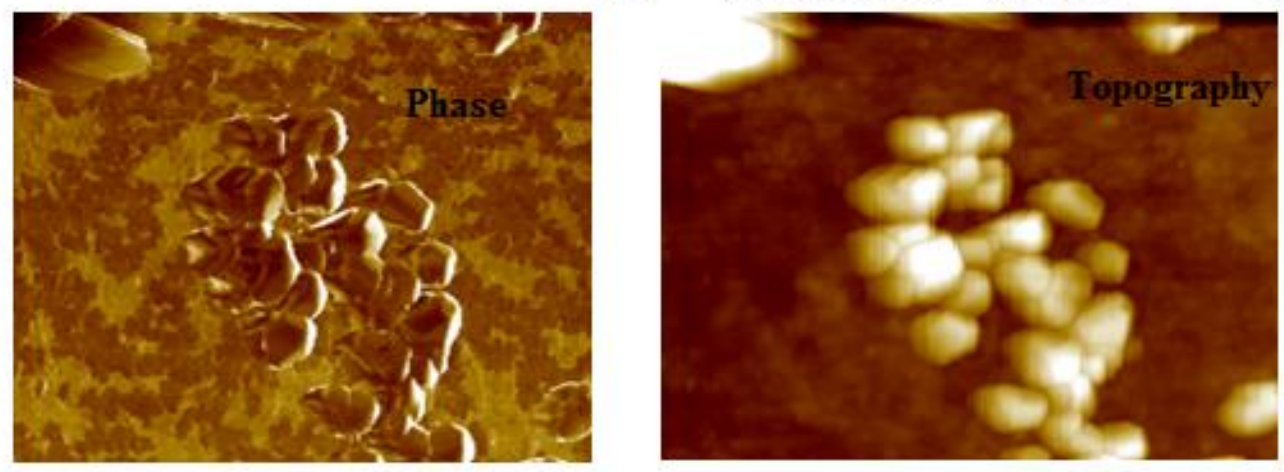

Figure 7.AFM images of untreated Chlorella cells.

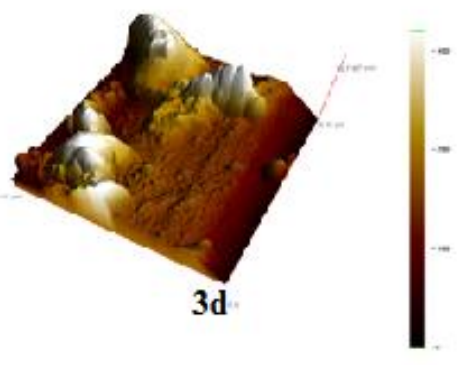

\begin{tabular}{|l}
\multicolumn{2}{c|}{ Roughness Parameters } \\
\multicolumn{1}{|c|}{ Coefficient } \\
\hline Average (Ra) \\
\hline Root Mean Squre (Ra) \\
\hline Skewness (Rsk) \\
\hline Kurtosis (Rku) \\
\hline Maximum (Rp) \\
\hline Minimum (RV) \\
\hline Peak To Peak (Rt) \\
\hline Ten Point Height (Rz) \\
\hline
\end{tabular}
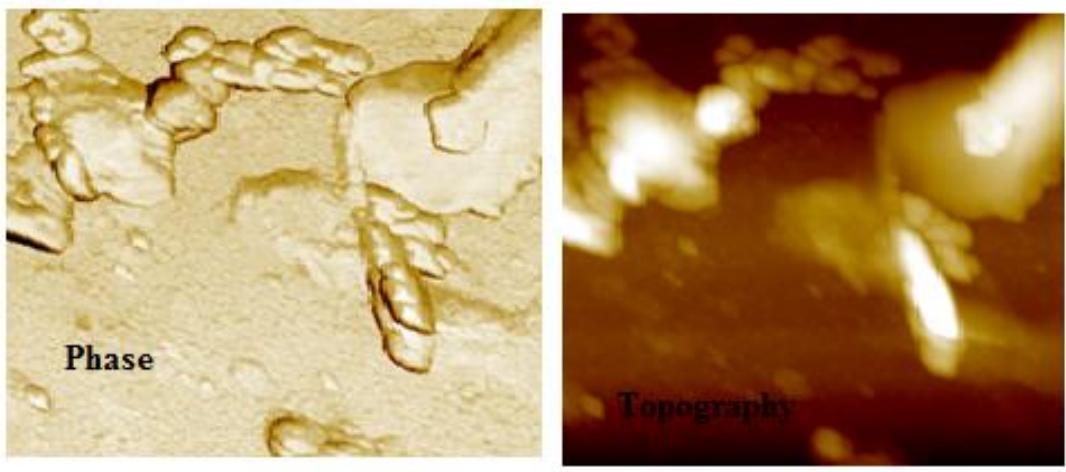

Figure 8. AFM images of treated Chlorella cells at 10 ppm heavy metal solution.

The AFM images of Scenedesmus cells were determined after the treatment with the metal mixture at the concentration of $5 \mathrm{ppm}$, which is the heaviest metal adsorption. Similar to Chlorella cells, Scendesmus cells treated-heavy metals showed deformation relative as compared with untreated cells revealed that Scenedesmus cells were cylindrical, have spines found in the terminal cells, and smooth before exposure to heavy metal (Figures 9-10). 


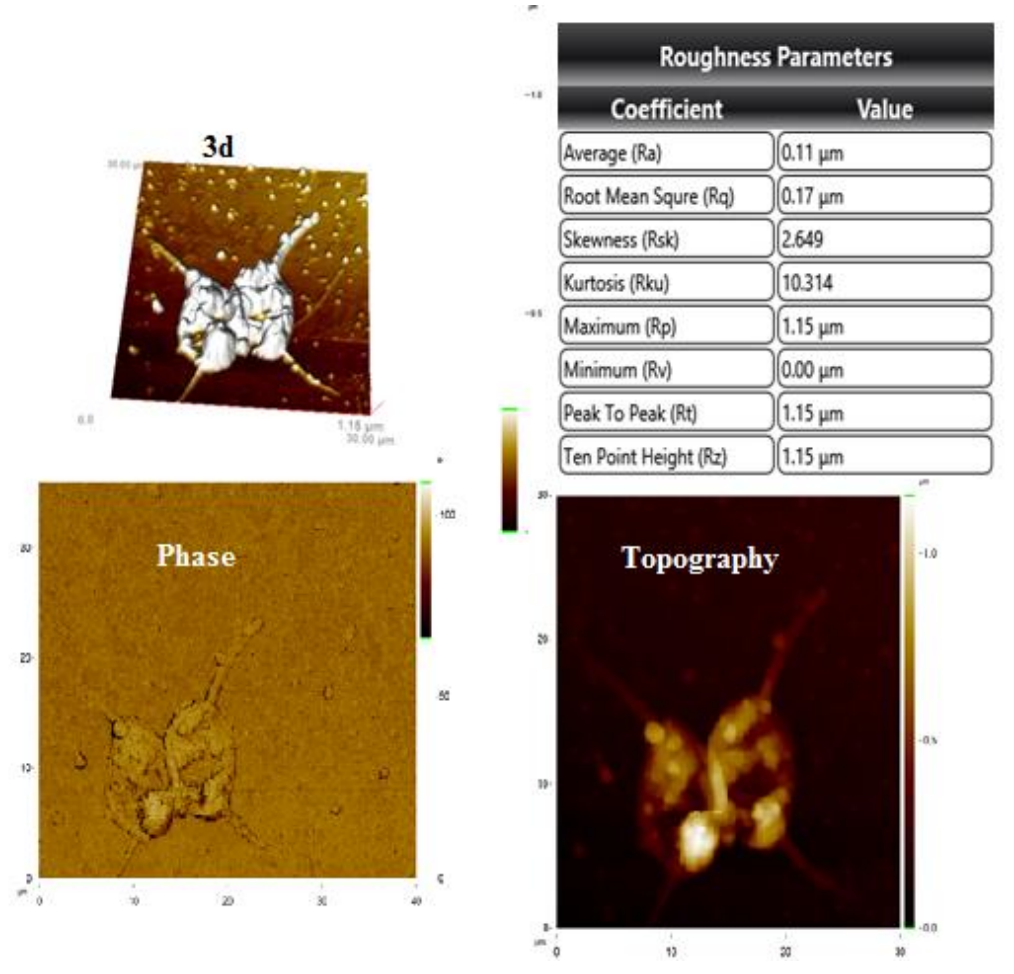

Figure 9. AFM images of untreated Scenedesmus cells.
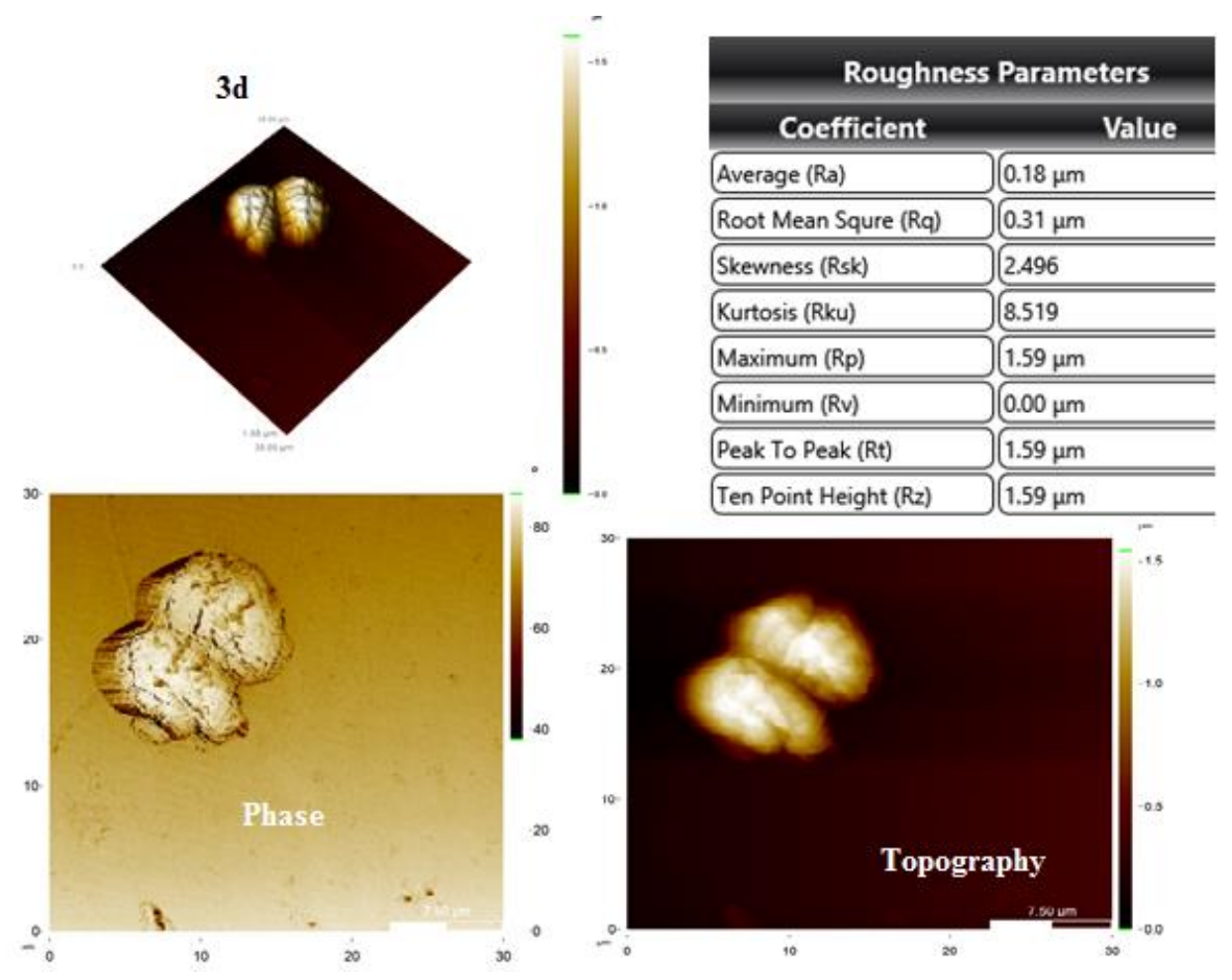

Figure 10. AFM images of treated Scenedesmus cells at $5 \mathrm{ppm}$ heavy metal solution. 


\section{DISCUSSION}

High metal concentrations cause significant toxic effects on enzyme systems that control biochemical and physiological processes such as photosynthesis, respiration and synthesis of biological molecules. Studies have been carried out that inhibit photosynthesis by inhibiting ion distribution and enzyme activity, especially in cyanobacteria and green algae in high-structure plants [20-22]. Chlorella and Scenedesmus cultures treated with heavy metals displayed chlorosis because a significant loss in chlorophyll-b content was observed within the 24 hours of experiment. Heavy metals had the greatest inhibitory effect at a concentration of chlorophyll-a and b in Scenedesmus cells.

Heavy metals were characterized by an inhibitory influence on the total carbohydrate content in a concentration-dependent manner. Therefore, the significant decrease in the level of total carbohydrate has been obtained under the high concentration of all heavy metals in Chlorella cells. The inhibitory effect of heavy metals on the total carbohydrate content was also arranged in the following order 50>100 >25>10 $\mathrm{ppm}$. The inhibitory effect of heavy metals on the content of total carbohydrates in $C$. vulgaris cells were suppressed by the coapplication of heavy metals. Rachlin and Grosso (1993) [23] found that Chlorella cells growth was inhibited under the influence of $\mathrm{Cd}$, $\mathrm{Cu}$ and $\mathrm{Co}$. They also reported that the effects of metals on the cell growth is $\mathrm{Cd}>\mathrm{Cu}>\mathrm{Co}$, respectively.

According to the results of the analysis, it was determined that four heavy metals tested in low and high concentration were inhibited on total chlorophyll-b contents of two green algae. This may be due to the high toxicity of high amounts of manganese and copper on the processes responsible for the chlorophyll-b biosynthesis. Decreases in the amount of chlorophyll in $\mathrm{Mn}$ effect onto Chlorella and Scenedesmus cells may result in degradation of the chlorophyll biosynthesis process, inhibition of the enzymes involved in chlorophyll biosynthesis, or degradation of chlorophyll. Previous studies have reported that heavy metals inhibit chlorophyll pigment biosynthesis and enzymes that work in this process (Senturk and Yildiz 2016) [24].

It has been found that low and high concentrations of heavy metal solutions in the study, especially Chlorella cells, give rise to stimulative effect on chlorophyll-a content. This suggests that Chlorella cells on chlorophyll-a synthesis are resistant to low and high heavy metals. The bioaccumulation of antimony, manganese, copper and nickel in the culture medium increased in parallel with the increase in concentration. We can say that the metal removal is positively correlated with the increase in the concentration of each metal up to the high enough amount to prevent growth.

Some of the methods of protection from metal toxicity of algae control metal pick-up, give back the exports of imported metals and hold the metals taken in an immobile form in the cell. The main purpose of these methods is to protect sensitive targets such as DNA and protein (Soldo et al., 2005) [25]. At the end of the $24 \mathrm{~h}$ incubation period, the percentages of removal on the antimony, manganese, copper and nickel of Chlorella biomass were $25.07 \%, 26.19 \%$, $41.02 \%$ and $62.01 \%$, respectively (The average adsorption capacity was determined to be 6.47 , 5.96, 28.57 and $10.71 \mathrm{mg} \mathrm{g}^{-1}$, respectively). Antimony and copper accumulation in Chlorella cells were observed to be higher at high antimony and copper concentrations $(25,50$ and $100 \mathrm{ppm})$ than the lower concentrations $(2.5,5$ and 10 ppm).Antimony and copper accumulation in Chlorella has also continuously increased at every concentration and time without showing a recession except the heavy metal at the concentration of $10 \mathrm{ppm}$. In the adsorption efficiency of the metals, synergistic and antagonistic effects are observed depending on the specific properties of these metals, the number and type of metal found in the media $[26,27]$. In other words, a metal can affect the amount of accumulation of another metal 
synergistically and antagonistically (Eg. antagonistic effect of $\mathrm{Cd}$ and $\mathrm{Zn}$ in some algal species or synergistic effect of $\mathrm{Ni}^{2+}$ and $\mathrm{Cu}^{2+}$ in membrane transport of metals). Lopez-Suarez et al. (2000) [28] found that $C$. vulgaris strongly binds heavy metals such as $\mathrm{Mn}, \mathrm{Cr}, \mathrm{Ni}, \mathrm{Zn}$ and $\mathrm{Cu}$ and they reported that the strongest bonds were observed for $\mathrm{Cr}$ and $\mathrm{Cu}$. The results of these reports were found to be consistent with the findings obtained in our study.

However, the percentages of heavy metal removal by Scenedesmus cells were $21.43 \%$, $13.86 \%, 13.97 \%$ and $20.50 \%$, respectively (The average adsorption capacity was determined to be 10.82, 7.07, 27.09 and $9.71 \mathrm{mg} \mathrm{g}^{-1}$ ). Antimony and Manganese can be attributed to the toxic effect on Chlorella cells and Scenedesmus cells, respectively. The same results were observed in the accumulation of copper on Scenedesmus cells. These results suggest that manganese and copper contained in the environment is taken up by two algae and stored in cell components of heavy metals or in specific metal binding proteins. Knauer et al. (1997) [29] reported that the accumulation of $\mathrm{Cu}$ on Scenedesmus subspicatus increased depending on the concentration. Fayed et al. (1983) [30] found that $\mathrm{Cu}, \mathrm{Zn}, \mathrm{Cd}$ and $\mathrm{Pb}$ were rapidly absorbed by Scenedesmus obliguus, inhibited the growth of algae [31], especially by copper, and inhibited cell division [32]. These results are consistent with the findings of our study.

The experimental data showed that for Chlorella and Scenedesmus cells, Langmuir isotherm model was applied to experimental equilibrium data of metal ions adsorption $\left(\mathrm{R}_{\mathrm{L}}\right)$ for $\mathrm{Mn}, \mathrm{Sb}, \mathrm{Ni}$ and $\mathrm{Cu}$ were found between $0.555-2.503$ and 0.015-0.355, respectively (Figure 3-6). For Chlorella and Scenedesmus cells, $1 / \mathrm{n}$ value was determined between 0.777-0.860 and 0.1020.375 , respectively. According to Kadirvelu and Namasivayam (2000) [33], $\mathrm{n}$ values between 1 and 10 indicate a useful adsorption representative. For a good adsorbent, $0.2<1 / \mathrm{n}<0.8$ and a smaller value of $1 / \mathrm{n}$ indicate better adsorption and formation of rather a strong bond between the adsorbate and adsorbent [34]. Based on the study results, $\mathrm{Mn}, \mathrm{Sb}, \mathrm{Ni}$ and $\mathrm{Cu}$ adsorption by Chlorella algae complies with Freundlich adsorption isotherm model, whereas Scenedesmus algae follows both Freundlich and Langmuir model. The algae biomass was effectively used as a sorbent for removal of metal ions from aqueous solutions. Sorption isotherms were well fitted to the Freundlich model, for four co-effective metal systems. In both adsorption models, the biomass showed a greater affinity for $\mathrm{Cu}$. The removal efficiency decreased with increasing metal concentration, pointing out a passive adsorption process involving the active sites on the surface of the biomasses.

\section{CONCLUSION}

High concentration of heavy metals, which are important contaminants of the water environment, is a consequence of human activities. Subsequent pollution toxicant affects the biochemistry, community and population levels of living things. Marine and freshwater algae, known as biological monitors of anthropogenic pollution, have a significant potential due to their ability to accumulate heavy metals in the environments and especially microalgae are beneficial in the remediation of various areas contaminated with inorganic nutrients and heavy metals [35]. For this reason, we are benefiting from the use of these two algal species as biosorbents in the heavy metal removal of water. Results from this study highlight the feasibility of Chlorella and Scenedesmus biomass as alternative low-cost biosorbents for the removal of $\mathrm{Cu}, \mathrm{Ni}, \mathrm{Sb}$ and $\mathrm{Mn}$ ions from aqueous solution. The heavy metal uptake ability of particularly Chlorella can be exploited for metal detoxification and environmental clean-up operations.

\section{ACKNOWLEDGEMENTS}

The authors wish to express their gratitude to the Celal Bayar University Scientific Investigation Project for the funding of this work (Project No. FEF 2014-079). 


\section{REFERENCES}

[1]. Aksu Z., Sag Y., Kutsal T. The biosorpnon of copperod by $C$. vulgaris and Z. Ramigera. Environ. Technol., 13 (1990) 579-586.

[2]. Wilde E.W., Benemann J.R. Bioremoval of heavy metals by the use of microalgae. Biotechnol Adv., 11 (1993) 781-812.

[3]. Garnham G.W. The use of algae as metal biosorbents. In: Biosorbents for metal ions: Taylor and Francis, London, 50 (1997) 11-37.

[4]. Wase D.A.J., Forster C.F., Yo Y.S. Biosorption of heavy metals: An introduction. In: Biosorbents for Metal Ions. Taylor and Francis, London, 50 (1997) 141- 163.

[5]. Torres E., Cid A., Herrero C. Abalde J. Effect of cadmium on growth, ATP content, carbon fixation and ultrastructure in the marine diatom Phaeodactylum tricornutum Bohlin. Water, Air, Soil Pollut., 117 (2000) 1-14.

[6]. Chouteau C., Dzyadevych S., Chovelon, J.M. Durrieu, C. Biosens. Development of novel conductometric biosensors based on immobilised whole cell Chlorella vulgaris microalgae. Bioelectron., 19 (2004) 1089-1096.

[7]. Durrieu C., Guedri H., Fremion F. Volatier L. Unicellular algae used as biosensors for chemical detection in Mediterranean lagoon and coastal waters. Res. Microbiol., 162 (2011) 908-914.

[8]. Monisha J., Tenzin T., Naresh A., Blessy B.M., Krishnamurthy N.B. Toxicity, mechanism and health effects of some heavy metals. Interdiscip Toxicol., 7 (2014) 60-72.

[9]. Stanier R.Y., Kunisawa R., Mandel M., Choen B. Purification and properties of unicellular blue- green algae (Order Chroococcales). Bacteriological Reviews, 35 (1971) 171-205.

[10]. Parsons T.R., Strickland J.D. Discussion of pectrophotometric determination of marine plant pigments, with revised equations for ascertaining chlophylls and carotenoids. J. Marine Research., 21 (1963) 115-63.

[11]. Dubois M., Gilles A.K., Hamilton J.K., Rebers, P.A., Smith, F. Colorimetric method for determination of sugars and related substances. Analytical Chemistry., 28 (1956) 350- 356.

[12]. Cucarella V., Renman G. Phosphorus sorption capacity of filter materials used for on-site wastewater treatment determined in batch experiments-a comparative study. J. Environ. Quality., 38 (2009) 381-92.

[13]. Freundlich H. Uber die adsorption in Losungen. Z. Phys. Chem., 57 (1907) 385-470.

[14]. Sari A., Tuzen M. Biosorption of $\mathrm{Pb}$ (II) andCd(II) from aqueous solution using green alga (UIva lactuca) biomass.J. of Hazardous Materials., 152 (2008) 302-08.

[15]. Khorramfar S., Mahmoodi N., Arami M. Dye removal from colored textile wastewater using tamarindus indica hull: Adsorption isotherm and kinetics study. J. Color Science Technology., 3 (2009) 8188.

[16]. Molazadeh P., Khanjani N., Rahimi M.Z., Nasiri A. Adsorption of lead by microalgae Chaetoceros sp. and Chlorella sp. from aqueous solution. J. Community Health Research., 4 (2015) 114-127.

[17]. Moiseenko TI., Kudryavtseva LP. Trace metal accumulation and fish pathologies in areas affected by mining and metallurgical enterprises in the Kola region. Environmental Pol., 114 (2001) 285-297.

[18]. Saleh T.A., Gupta V.K. (a). Photocatalyzed degradation of hazardous dye methyl orange by use of a composite catalyst consisting of multiwalled carbon nanotubes and titanium dioxide. J. Colloid Interface Sci., 371 (2012) 101-106.

[19]. Saleh T.A., Gupta V.K. (b). Synthesis and characterization of alumina nano-particles polyamide membrane with enhanced flux 
rejection performance. Sep Purif Technol., 89 (2012) 245-251.

[20]. Foy C.D. I., Chaney R.L.,White M.C. Crassulacean acid metabolism: A curiosity in context. Annual Review of Plant Phys., 29 (1978) 551- 566.

[21]. Rai L.C., Gaur J.P., Kumar H.D. Phycology and heavy-metal pollution. Biol. Rev. Cambridge Philos. Soc., 56 (1981) 99- 151.

[22]. Heath R.L. Possible mechanisms for the inhibition of photosynthesis by ozone. Photosynth. Res., 39 (1994) 439-451.

[23]. Rachlin J.W., Grosso A. The growth response of the green alga Chlorella vulgaris to combined divalent cation exposure. Arch. Environ. Contam. Toxicol., 24 (1993) 16-20.

[24]. Senturk, T., Yildiz, S. Adsorbent effect of Chlorella vulgaris and Scenedesmus sp. (Chlorophyta) for the removal of some heavy metals and nutrients. Turkish J. Biochem., 41 (2016) 87-95.

[25]. Soldo D., Hari R., Sigg L., Behra R. Tolerance of Oocystis nephrocytioides to copper: intracellular distribution and extracellular complexation of copper. Aquatic Toxicol., 71 (2005) 307- 317.

[26]. Ting YP., F. Lawson LG. Uptake of cadmium and zinc by the alga Chlorella vulgaris: II. Multi-ion situation. Biotechnol. Bioeng., 37 (1991) 445-455.

[27]. Volesky B., R May R, Holan Z.R. Biosorption of cadmium by biomass of marine algae. Biotechnology and Bioeng., 41 (1993) 826-289.

[28]. Lopez-Suarez C.E., Castro-Romero J.M., Gonzalez-Rodriguez M.V., GonzalezSoto E., Perez-Iglesias J., Seco-Lago H.M., Fernandez-Solis J.M.S. Study of the parameters affecting the binding of metals in solution by Chlorella vulgaris. Talanta, 50 (2000) 1313-1318.

[29]. Knauer K., Behraa R., Sigg L. Effects of free $\mathrm{Cu}^{2+}$ and $\mathrm{Zn}^{2+}$ ions on growth and metal accumulation in freshwater algae. Environ. Toxicol. Chem., 16 (1997) 220229.
[30]. Fayed Sami E., Abdel S., Hussein I., Khalifa Nadia M. Accumulation of $\mathrm{Cu}$, $\mathrm{Zn}, \mathrm{Cd}$ and $\mathrm{Pb}$ by Scenedesmus obliquus under nongrowth conditions. Environment Inter., 9 (1983) 409-413.

[31]. Kessler E. Limits of growth of live Chlorella species in the presence of toxic heavy metals. Arch. Hydrobiol., 73 (1986) 123-128.

[32]. Guanzon N.G.J.R., Nakahara H., Yodhida Y. Inhibitory effects of heavy metals on growth and photosynthesis of three freshwater microalgae. Fish. Sci., 60 (1994) 379-384.

[33]. Kadirvelu K., Namasivayam C. Agricutural by-product as metal adsorbent: Sorption of Lead(II) from aqueous solution onto coirpith carbon. Environmental Techn., 21 (2000) 10911097.

[34]. Basha S., Keane D., Morrissey A., Nolan K., Oelgemöller M., Tobin J. Studies on the adsorption and kinetics of photodegradation of pharmaceutical compound, indomethacin using novel photocatalytic adsorbents (IPCAs). Ind. Eng. Chem. Res., 49 (2010) 1130211309.

[35]. Jaishankar M., Tseten T., Anbalagan N., Blessy B. Mathew, Krishnamurthy N. Toxicity, mechanism and health effects of some heavy metals. Interdiscip Toxicol., 7 (2014) 60-72. 